\title{
Implementácia autentického materiálu do výučby odborného cudzieho jazyka
}

\author{
Implementation of authentic material in teaching professional \\ foreign language
}

\author{
Iveta Rizeková
}

\begin{abstract}
Abstrakt: Príspevok sa zaoberá problematikou didaktického využitia autentického materiálu vo výučbe cudzieho jazyka v kontexte aplikovanej lingvistiky. Autorka príspevku vychádza z presvedčenia, že autenticita má v cudzojazyčnej výučbe dôležité miesto, pretože prejavy a dokumenty určené rodeným hovoriacim v danej krajine sprostredkúvajú kontakt so situáciami z reálneho života aj so živým jazykom. Článok prináša možnosti využitia jednotlivých typov autentických dokumentov na hodinách odborného cudzieho jazyka a prezentuje výsledky dotazníkového prieskumu uskutočneného v radoch študentov aplikovaných jazykov. Cielom prieskumu bolo zistit', aké je zastúpenie jednotlivých typov autentického materiálu a ako efektívne sa využíva na hodinách odborného francúzskeho jazyka, ako aj to, aký je postoj študentov k otázke implementácie autentických materiálov do jazykovej výučby. Autorka v závere konštatuje, že autentické zdroje významne prispievajú k rozvoju komunikačných zručností a vnímaniu interkultúrnych rozdielov a pozitívne vplývajú na motiváciu študentov. Hodiny jazyka sa vd’aka nim stávajú dynamickými, interaktívnymi a viac orientovanými na potreby učiacich sa.
\end{abstract}

Klúčové slová: aplikovaná lingvistika, autentický materiál, implementácia, odborná francúzština, vyučovacie metódy

\begin{abstract}
The paper deals with the utilisation of authentic material in teaching professional foreign language within the context of applied linguistics. The author states her persuasion that authenticity has an important place in foreign language teaching as the speeches and documents meant for native speakers of the given country mediate a contact to real-life situations and real language. The article presents various possibilities on how to use different authentic documents in the lessons of professional foreign language and presents the results of a questionnaire survey carried out among the students of applied languages. The research aimed to find out the representation of different types of authentic material and how effective is their use in the lessons of the professional French language, in addition to the attitude of students towards the implementation of authentic materials in language classes. In the conclusion, the author claims that authentic sources contribute significantly to the development of communicative skills and perception of intercultural differences and positively influence the students' motivation. The language classes become due to authenticity more dynamic, interactive and more learner-oriented.
\end{abstract}

Key words: applied linguistics, authentic material, implementation, professional French, teaching methods 


\section{1 Úvod}

V oblasti cudzojazyčného vzdelávania sa v posledných desat'ročiach preferuje komunikatívny prístup, ktorý je podporovaný myšlienkou humanizácie vyučovania a rozvíjania komunikatívnych kompetencií využitel'ných v praxi. Komunikatívny prístup chápe jazyk ako celok, uprednostňuje učenie ústneho a písomného prejavu v spojitosti, dôraz kladie na autentické úlohy, porovnatel'né s reálnym životom. Patrí k nim napríklad prijímanie alebo odovzdávanie informácií, vyjadrenie vlastného názoru na danú problematiku, kritické posudzovanie, formulovanie a riešenie problémov atd'. $\mathrm{S}$ takýmito typmi úloh sa môžu študenti stretnút' v bežnom živote i v profesionálnej komunikácii.

V príspevku sa venujeme problematike implementácie autentických materiálov do výučby odborného cudzieho jazyka. Opierame sa pritom o vlastné pedagogické skúsenosti získané na Fakulte aplikovaných jazykov Ekonomickej univerzity v Bratislave, ktorá má za ciel' prehlbovat' komunikatívne kompetencie študentov v dvoch cudzích jazykoch a poskytovat' vedomosti a zručnosti vo sfére odbornej a interkultúrnej komunikácie. Jazyková výučba je aplikovaná na oblast' ekonomických vied a vybraných spoločenskovedných disciplín, ktoré umožňujú absolventom fakulty uplatnit' sa v štátnom, verejnom či súkromnom sektore, vo firmách a inštitúciách s medzinárodnou pôsobnostou. Prax nás neustále presviedča, že na takto postavené ciele výučby aplikovaných jazykov nestačí používat' iba učebnicový materiál, ktorý každým rokom zastaráva a len v obmedzenej miere spíňa kritérium autenticity a spätosti $\mathrm{s}$ reálnym životom. Moderné vyučovacie prístupy si vyžadujú pravidelné začleňovanie takých aktivít, ktoré vychádzajú z autentických prameňov a stimulujú autentické verbálne či neverbálne reakcie. Ďalším zdrojom nášho poznania boli názory študentov aplikovanej lingvistiky. Metódou dotazníkového prieskumu sme zistovali, aké miesto zaujíma autentický materiál a ako efektívne je využívaný na hodinách odborného francúzskeho jazyka.

\subsection{Autentický materiál a jeho zdroje}

Do škôl vstúpili autentické dokumenty v 70. rokoch minulého storočia a do jazykového vzdelávania sa dostali prostredníctvom nového komunikačného prístupu, v ktorom sa stali klúčovým pojmom (Cuq, 2003, s. 29). Móda autentického materiálu sa rozvinula $\mathrm{v}$ didaktike jazykov $\mathrm{v}$ podstate ako reakcia na relatívnu „umelost" dialógov v audio-orálnych a audio-vizuálnych učebniciach. Študenti sa prostredníctvom nich dostávali do styku iba so zjednodušeným jazykom, ktorý bol upravený a ochudobnený o sociálno-kultúrny rozmer, teda s jazykom dost' odlišným od toho, aký používajú rodení hovoriaci. Z toho vyplynula didaktická úvaha, že ak budú učiaci sa v triede od začiatku konfrontovaní s ukážkami autentického jazyka, budú lahšie zvládat' komunikačné praktiky mimo triedy a navyše budú viac motivovaní (Cortes, 1987, s. 184-185). 
Princíp autentickosti zdôrazňuje maximálne priblíženie sa reálnej komunikácii, čiže komunikácii, ktorá je imanentná reálnemu životu (Repka, 1997, s. 66-67). Podla Homolovej má autentický materiál mnohoraké podoby a formy a bol vytvorený v danej krajine pre jej obyvatelov, teda rodených hovoriacich, a určený pre ich každodenné potreby (Homolová, 2003, s. 7). Analogicky sa v definícii Jeana-Pierra Cuqa pod autentickým materiálom (vo francúzskom kontexte je zaužívané označenie „document authentique ${ }^{1 \text { ") }}$ rozumie každý odkaz, ktorý vytvorili po francúzsky hovoriaci za účelom reálnej komunikácie s po francúzsky hovoriacimi (CUQ, 2003, s. 29). Stretávame sa aj s rozlišovaním „autentického“ dokumentu, čiže dokumentu bez akejkolvvek úpravy, „polo-autentického“ dokumentu, čiastočne modifikovaného, a „vytvoreného“ dokumentu (Couto Silva, 2015, s. 109).

Niektorí teoretici zastávajú názor, že autentický dokument vytrhnutý z kontextu a následne použitý v inom kontexte už stráca pravú autenticitu. Iní sú presvedčení, že každý autentický materiál použitý v triede musí byt' nevyhnutne adaptovaný na konkrétne podmienky výučby.

Zdrojom autentického materiálu môžu byt' noviny, časopisy, knihy, zborníky, slovníky, obrázky, korešpondencia, webové stránky, blogy, filmy a pod. Dnes sú už dostupné nielen v printovej, ale aj v elektronickej forme a prenosné na CD, DVD, USB nosičoch, prostredníctvom internetu, mailovej komunikácie, sociálnych sietí atd'. Aj pri cudzojazyčnom vzdelávaní sa dá čerpat’ z bohatého inventára typov autentických dokumentov. Napríklad:

a) zvukový materiál: rozhlasové vysielanie, správy, nahraný monológ a dialóg, telefonický rozhovor, interview, prednáška, reklama, pieseň;

b) vizuálny materiál:

- obrazový: fotografia, kresba, ikona, graf;

- textový: kniha, brožúra, list, e-mail, formulár, databáza;

- kombinovaný - graf s popisom, reklamný plagát, mapa;

c) audiovizuálny materiál: film, videoklip, videonahrávka prednáška alebo diskusia, televízny prenos správ a i.

Jednotlivé typy dokumentov sa dajú kombinovat' v závislosti od toho, v ktorej fáze vyučovania sú použité a s akým konkrétnym zámerom a komunikačným cielom sú spojené.

1 Preklad „autentický dokument“. 


\subsection{Pozitíva a úskalia výučby s autentickým materiálom}

Je nepopieratel'né, že autentický materiál obohacuje čitatela, poslucháča alebo diváka, pretože mu prináša nové aktuálne poznatky z rôznych oblastí spoločensko-ekonomického a kultúrneho života obyvatelov danej krajiny.

Klúčovým cielom modernej jazykovej výučby je formovat' a rozvíjat' komunikačnú jazykovú kompetenciu, ktorú treba chápat' ako systém jazykových, sociolingválnych a pragmatických zložiek (SERR, 2017, s.17). A v čase globalizácie je dôležitost' systematického spájania jazykového rozmeru s kultúrnym a interkultúrnym kontextom na školách nepopieratel'ná. Rôzne druhy autentických prejavov vždy odrážajú určité kultúrno-spoločenské pozadie danej society a daného regiónu, a preto sú ideálnym zdrojom pre nadobudnutie komplexného poznania. Autentický materiál je zaujímavý a lákavý aj pre učiacich sa cudzí jazyk, pretože s prirodzenou túžbou po poznaní a vrodenou zvedavostou získat' nové poznatky v odbore sa podl'a nás rodí aj túžba ovládat' nástroj, ktorý takéto nové poznanie umožní sprostredkovat', čiže jazyk.

Okrem získania nových informácií si človek osvojuje aj nové pojmy, výrazy (vrátane odborných), jazykové spojenia, štylistické konštrukcie a v závislosti od typu zdroja aj pravopis či výslovnost'. Toto obohacovanie sa môže diat' podvedome, ale aj pomocou vedomého usmerňovaného vnímania, a to najmä vtedy, ked' je človek v roli učiaceho sa. Vedomú percepciu autentického prejavu, jeho obsahu a formy, ovplyvňuje učitel', jednak výberom materiálu, jednak prípravou úloh a aktivít, ktoré autentický materiál didakticky sprevádzajú a dopíňajú. Selekcia autentických dokumentov a tvorba sprievodných zadaní je náročná práca, ktorá si od pedagóga vyžaduje vela času, predstavivosti a kreativity, ale aj dobré orientovanie sa v metódach vyučovania s autentickým materiálom. Základným predpokladom dosiahnutia želaných výsledkov v takto nasmerovanej výučbe je adekvátne spojenie autentického materiálu s aktivitami smerujúcimi k dosiahnutiu stanovených vyučovacích cielov.

Učitel' vyberá autentický materiál a konkretizuje čiastkové ciele cudzojazyčnej výučby so zretelom na vek a záujmy, jazykovú úroveň a jazykové potreby učiacej sa skupiny. Netreba zabúdat' ani na skutočnost', že proces odkrývania niečoho nového, alebo spokojnost' z naplnenia potreby či vyriešenia problému stimuluje okrem myslenia aj pocitovú stránku výučby, čím podporuje radost’ z poznávania a prispieva $\mathrm{k}$ dobrej nálade.

Okrem vyššie uvedených pozitív vyplývajúcich z úspešnej implementácie autentického materiálu do výchovno-vzdelávacieho procesu je nutné uviest', že sprievodným javom hladania riešení problémovo postavených úloh je uplatnenie vyšších myšlienkových procesov učiacich sa, akými sú napríklad analyzovanie a syntetizovanie faktov, javov, myšlienok, dedukcia, vytváranie hypotéz, argumentácia, na- 
vrhovanie postupnosti krokov či metód, formulovanie záverov a pod. Študentom sa môžu spočiatku javit’ takéto činnosti ako značne náročné, dokonca nezvládnutel'né, najmä v rámci písomného prejavu. Ich pozitívom však je to, že každý jednotlivec má pri nich možnost' preukázat' svoje individuálne schopnosti a kreativitu, čo vedie $\mathrm{k}$ jeho autonómii, $\mathrm{k}$ posilneniu sebavedomia a motivácie dálej sa vzdelávat' a napredovat' (aj v jazyku).

Ďalším pozitívom autentických dokumentov v jazykovej výučbe je fakt, že hlbšie a komplexnejšie rozvíjajú poznanie danej problematiky, ktorá je sprostredkovaná prirodzeným jazykom zodpovedajúcim konkrétnej komunikačnej situácii. To všetko pripravuje učiaceho sa na plnenie úloh v spoločenskom a profesionálnom živote.

Priznávame, že pri procese implementácie do výučby treba niekedy autentický charakter dokumentov čiastočne modifikovat'. Ked' sa stávajú predmetom jazykového a kultúrneho poznávania, sú vytiahnuté z pôvodného kontextu a zasadené do iného času a priestoru, menia svojho adresáta aj funkciu. „Kontext je významným faktorom, ktorého chápanie alebo ignorovanie môže podporit' alebo naopak prekazit’ úspech komunikácie“ (Hrivíková, 2012, s. 73). Podla Cortesa autentický dokument naráža v didaktike na dva druhy t'ažkostí: prvé majú kultúrnu alebo komunikačnú povahu, druhé skôr jazykovú a gramatickú. $\mathrm{V}$ prvom prípade autentický dokument spája nevyhnutne dve alebo viaceré kultúry, na jednej strane tú, z ktorej vzišiel a na druhej strane, kultúrnu a jazykovú skúsenost' vlastnú učiacim sa, respektíve predstavu, ktorú si o kultúre a jazyku autentického dokumentu vytvorili. Na to, aby mohol takýto dokument plnit' svoju didaktickú funkciu, musí byt' vyňatý z pôvodných komunikačných podmienok (pre ktoré vznikol) a začlenený do pedagogických komunikačných podmienok, pre ktoré nebol predurčený, ani jazykovo, ani kultúrne, ani pragmaticky. To, čo sa v triede odovzdáva, nie je autenticita dokumentu (podmienky, ktoré pôvodne garantovali komunikáciu), ale jeho integrita. Ide tu o tzv. interpretačný posun, ktorý následne vyvoláva nepochopenie, niekedy dokonca nesprávne chápanie (Cortes, 1987, s. 186). V školskom prostredí sa teda neprihliada iba na autenticitu, pretože sa musia sledovat' ciele výučby smerujúce k získaniu poznatkov, zručností a kompetencií.

Jazyková a štylistická pestrost' autentických dokumentov môže byt' výhodou, ale rovnako môže spôsobovat' i t'ažkosti. Obohatením sú všetky zdroje, ktoré sprostredkúvajú dôveryhodnú komunikáciu v cielovom jazyku a bližšie oboznamujú s ciel'ovou kultúrou. Autentické zdroje nabádajú vyučujúceho varírovat' didaktický materiál tak, aby motivoval a prekvapoval učiacich sa a zároveň ich kontaktoval s rečou vo všetkých jej formách a prejavoch (Defays, 2003, s. 263). Študenti však môžu mat' určité problémy s porozumením (najmä pri nižšom stupni jazykovej kompetencie), v dôsledku čoho často strácajú motiváciu $\mathrm{k}$ učeniu. $\mathrm{Z}$ uvedených 
dôvodov tu dôležitú úlohu zohráva učitel', ktorý by mal dokázat' toto špecifikum autenticity vo výučbe metodicky využit'.

Pracovníčka z francúzskeho Centra výskumu jazykovej diverzity frankofónie odporúča učitel’om jazyka, aby sa vopred dôkladne oboznámili s autentickým dokumentom, ktorý na hodine použijú, posúdili relevantnost' jeho témy pre daný kurz, adekvátnost' jazykovej stránky vo vzt'ahu k svojmu publiku, ale tiež spol'ahlivost' informácie sprostredkovanej dokumentom. Autorka pripúšt’a možnost' modifikácie dokumentu v prípade potreby: napríklad pri textovom zdroji vynechanie zložitých pasáží, nahradenie problematických výrazov jednoduchšími alebo uvedenie vysvetlenia menej zrozumitel'ných štruktúr (Lemeunier-Quéré, 2006).

Obsahová a jazyková relevantnost' sú teda rozhodujúcimi prvkami pri plánovaní aktivít pre konkrétnu vyučovaciu jednotku. Je dôležité, aby učitel' dokázal vhodne spojit' vybraný materiál s učebnými aktivitami rešpektujúcimi didaktické princípy práce s autentickým textom, obrazovým a/alebo zvukovým materiálom. V dlhšom horizonte si môže vyučujúci z osvedčených dokumentov vytvorit' databázu, ktorú môže využit' na hodinách opakovane, poprípade spracovat' a vytlačit' ako učebnú pomôcku aj pre d'alšie ročníky študentov.

\subsection{Autentický materiál vo výučbe odborného cudzieho jazyka}

Je zrejmé, že odborný prejav sa vyznačuje odborným obsahom, ktorý je jazykovo realizovaný odbornou terminológiou. Termíny sú jednoznačné, presné a definovatel'né výrazy, pre ktoré je charakteristická objektívnost' a štylistická bezpríznakovost'. Autentický odborný prejav obsahujúci množstvo odborných výrazov neraz komplikuje študentom porozumenie. Jeho náročnost' sa môže zvyšovat' úmerne s jeho dĺžkou. Na druhej strane určitou výhodou takéhoto materiálu je jeho tematická spojitost' so zameraním a odborom štúdia, ktoré si študent dobrovol'ne vybral (a predpokladá sa, že aj so záujmom), ktorá mu pomáha l'ahšie dekódovat' odborný obsah a navyše podnecuje jeho záujem.

Niektorí autori odmietajú začleňovanie autentických dokumentov do výučby v skupinách s nižšou jazykovou úrovňou pre zložitost' jazyka, výskyt menej používaných slov a náročných myšlienkových operácií, ktorým učiaci sa nerozumejú, ale najmä pre ich nedostatočnú slovnú zásobyu. Ako konštatuje Čuriová, mnohé t’ažkosti v receptívnom aj produktívnom používaní jazyka sú výsledkom nedostatočnej a neprimeranej slovnej zásoby študentov. Študenti často komunikujú pomocou obmedzenej lexiky, jednoduchých slov a pomenovaní, ktoré majú hlboko zakorenené. Do istej miery dokážu komunikovat' aj s chudobnou slovnou zásobou, a preto nepocitujú potrebu d’alej ju rozvíjat' (Čuriová, 2017, s. 14-15). Sme presvedčení, že materiál čerpaný z autentických zdrojov má potenciál rozširovat' aj všeobecnú a odbornú lexikálnu zásobu študentov, ktorá je nevyhnutná pre adekvátne a pres- 
né pomenovanie faktov, javov, súvislostí. Je dôležité, aby práca s autentickým dokumentom bola spojená s adekvátnymi receptívnymi a produktívnymi činnostami.

Ak chápeme autenticitu $v$ širšom zmysle, čiže máme na mysli nielen úplne autentické, ale i modifikované prejavy, potom jej prítomnost' na hodinách pokladáme za nevyhnutnost'. Pri zohladnení faktora jazykovej úrovne prijímatel'a napríklad pri počúvaní s porozumením, pokladáme za vhodnejšie použit' úplne autentické zvukové dokumenty pre úroveň $\mathrm{C} 1$ a $\mathrm{C} 2$, modifikované pre úroveň $\mathrm{B} 1 \mathrm{a} \mathrm{B} 2$ a vytvorené dokumenty pre úroveň A1 a A2. Pri výbere materiálu treba pamätat' na jasnost' zvukového úryvku, obsahovú celistvost’ aj logickú ukončenost' (Kvapil, 2015, s. 44).

Pokým vo vyučovaní všeobecného jazyka stále prebiehajú diskusie o využívaní adaptovaných a autentických textov, pri odbornom cudzom jazyku sa autori vzácne zhodujú na potrebe využívat' autentický materiál tak, aby daný text predstavoval pre učiaceho sa model, ktorý sa snaží imitovat' (Gajdáčková Veselá, 2017, s. 12)

Vychádzajúc z vlastnej pedagogickej praxe môžeme konštatovat', že autentický materiál sa dá účinne implementovat' aj do výučby na mierne pokročilej, dokonca i začiatočníckej úrovni. Dôležité je vediet' odhadnút' správny rozsah a funkciu, akú bude takýto prvok na hodine plnit'. Môže to byt' napríklad počúvanie krátkeho prejavu s ciel'om zachytit' klúčové slová, identifikovat' tému, prostredie, osoby, produkty a pod. Sme presvedčení, že aj porozumenie jednoduchého autentického prehovoru či textu môže byt' pre učiaceho sa silným motivujúcim prvkom.

\subsection{Druhy aktivít $v$ jednotlivých fázach vyučovacieho procesu}

Autentický dokument môže byt' implementovaný do akejkolvek fázy vyučovacieho procesu odborného cudzieho jazyka, vždy však s ohl'adom na konkrétny vyučovací ciel'.

V počiatočnej, tzv. zahrievacej alebo motivačnej, fáze hodiny sú osvedčené také úlohy, ktoré vzbudia záujem, navodia priaznivú atmosféru na hodine a zároveň pripravia na prácu s cudzojazyčným textom. Autentický dokument tu býva použitý ako stimulačný prvok pri opakovaní už známeho učiva alebo pri otvorení novej témy. Často ide o časovo menej náročné aktivity, ktoré však už od začiatku podnecujú študentovu kreativitu a aktivitu. K takým činnostiam patrí napríklad:

- práca s obrázkom, fotografiou, plagátom, ktorej ciel'om je pomenovat' a opísat' osoby, veci, činnosti, situácie v rámci opakovania lexiky;

- uvedenie obrazového/zvukového/video dokumentu s cielom identifikovat' novú tému a naštartovat' brainstorming na danú tému;

- práca s paratextom (nadpisom, podnadpisom, mottom) s cielom určit' zdroj, kontext, problematiku, modifikovat' znenie; 
- práca s údajmi (tabul'kami, grafmi) s cielom zopakovat' lexikálne či gramatické javy, porovnat' a analyzovat' kvantitatívne a kvalitatívne ukazovatele.

V nasledujúcej fáze hodiny sú autentické materiály hojne využívané na rozvíjanie odbornej slovnej zásoby, osvojovanie si termínov, vysvetlovanie a definovanie nových pojmov. Existuje vela spôsobov práce a hier s klúčovými slovami, termínmi, idiomatickými výrazmi, ako napríklad:

- hladanie významu slov a definície vo výkladovom, synonymickom, frazeologickom, slangovom slovníku;

- prirad'ovanie definícií k termínom, príp. vytváranie vlastných definícií;

- priradovanie prívlastkov k substantívam a vytváranie terminologických pomenovaní;

- práca s lexikálnymi polami a kolokáciami atd'.

V d’alšej fáze, teda $v$ hlavnej časti vyučovacej jednotky, býva autentický dokument použitý spravidla na sprístupnenie nových poznatkov o danej problematike. Úlohy sú tak komplexnejšie a ich plnenie si vyžaduje dlhší čas. Môže íst' o aktivity, ktoré študenti vykonávajú súbežne so sledovaním dokumentu alebo po jeho ukončení.

Počas počúvania alebo sledovania autentického dokumentu je možné oddelit' obraz od zvuku, avšak vždy zmysluplne a s ohladom na konkrétne zadanie. Náročnejší obsah a dlhší jazykový prejav sa zvykne sledovat' opakovane, najprv v celku a následne po segmentoch. $\mathrm{K}$ najčastejším aktivitám $\mathrm{v}$ rámci prvého oboznamovania sa s dokumentom patria:

- zachytávanie počutých/videných slov, vecí, osôb;

- zachytenie a zápis klúčových slov, myšlienok;

- zachytenie a zápis postupnosti, bodov osnovy, štruktúry dokumentu.

K úlohám zameraným na porozumenie dokumentu až po jeho sledovaní/prečítaní /vypočutí môžeme zaradit' nasledovné:

- odpovedanie na otázky (zatvorené, otvorené, typu pravdivé - nepravdivé);

- vyhladávanie jazykových prostriedkov a ich explikácia;

- definovanie pojmov;

- modifikovanie textu (práca so synonymami, antonymami);

- dopíňanie vynechaných výrazov v texte;

- zaznamenanie štruktúry textu pomocou schém, grafov, tabuliek;

- robenie poznámok;

- hladanie a analyzovanie detailov, podobností a rozdielov; 
- zachytenie a reprodukovanie myšlienok, postojov a názorov a pod.

Čítanie s porozumením je primárnou zručnost’ou pri práci s odborným textom. S materiálom textového charakteru sa dá pracovat' už počas jeho prvého čítania alebo po prečítaní. Učitel' môže textový zdroj sprístupňovat' po segmentoch a prispôsobit' tak jeho porozumenie jazykovej úrovni študentov alebo konkrétnym časovým podmienkam. Dlhšie texty informatívneho charakteru sú vhodné na skupinovú prácu, ktorá môže spočívat’ v:

- identifikovaní obsahových segmentov v texte (bez odsekov);

- dopíňaní údajov do textu;

- zorad’ovaní poprehadzovaných segmentov textu do chronologickej alebo logickej postupnosti;

- kategorizácii slov, viet, informácií (na základe obsahového, gramatického hl'adiska)

- vyhladávaní informácií v texte a pod.

Je zrejmé, že $\mathrm{v}$ rámci všetkých úloh dochádza $\mathrm{k}$ rozvíjaniu lexikálnej zásoby a k rozširovaniu a zdokonalovaniu jazykových a komunikačných prostriedkov. Napríklad vo francúzštine sa do porovnávania situácie a javov z chronologického hladiska (kedysi a dnes) dá vhodne zakomponovat' učivo o gramatických časoch (prézent a minulé časy), pri formulovaní predpokladov budúceho vývoja (budúce časy), pri vyjadrovaní želaní a preferencií (konjunktív), pri stanovovaní podmienok a hypotéz (podmieňovací spôsob a podmienkové vety) atd'.

Okrem aktivít smerujúcich $\mathrm{k}$ porozumeniu počutého, čítaného či videného dokumentu sa všetky druhy autentického materiálu dajú použit' aj ako východisko pre aktivity produktívne, písomné či ústne, individuálne i skupinové, pripravované v školskom alebo domácom prostredí. K najfrekventovanejším činnostiam zameraným na ústny prejav, ktoré nasledujú po percepcii autentického dokumentu patria:

- zhrnutie obsahu textu/prehovoru;

- vytvorenie úvodu alebo záveru k textu/prehovoru;

- simulácia rozhovoru/interview na základe textu;

- hladanie spôsobov riešenia nastoleného problému;

- vyjadrenie vlastného názoru, postoja, skúsenosti;

- diskusia na danú odbornú tému v skupinách;

- preklad a tlmočenie myšlienok v texte/prejave;

- príprava, realizácia, prezentácia a evaluácia projektovej úlohy.

Z úloh rozvíjajúcich písomný prejav môžeme spomenút: 
- napísanie listu na základe textu, mailu;

- napísanie zhrnutia, správy, resumé, abstraktu;

- preklad textu z a do materinského jazyka;

- napísanie odborného článku;

- zostavenie a napísanie záverečnej práce.

S rozvojom moderných technológií sa výrazne zmenila aj štruktúra vyučovacích hodín cudzieho jazyka. $\mathrm{V}$ univerzitnom štúdiu sú ich dôležitou súčast'ou, tak zo strany učitela, ako aj študenta, prezentácie, ktoré sú vytvorené na základe autentických zdrojov, ked'že ich témy sú prevzaté z reálneho prostredia a sprostredkúvajú odborné vedomosti. Prezentácie podporujú diskusie o odborných témach, stimulujú interaktívnu konverzáciu s učitelom aj spolužiakmi a následné rozvíjajú aj písomný prejav.

\section{Metodológia: Autentický materiál na hodinách odborných predmetov vo francúzskom jazyku}

Na zistenie, do akej miery a s akou účinnostou sa implementuje autentický materiál do procesu výučby aplikovaných jazykov, sme realizovali dobrovol'ný dotazníkový prieskum na Fakulte aplikovaných jazykov Ekonomickej univerzity v Bratislave. Za cielovú skupinu sme vybrali študentov jazykovej kombinácie angličtinafrancúzština v študijnom programe "Cudzie jazyky a interkultúrna komunikácia“. Otázky sa týkali konkrétne výučby odborného francúzskeho jazyka, ktorá zahŕňa povinné a povinne výberové predmety: ekonomická a podniková francúzština, francúzština $\mathrm{v}$ akademickom prostredí, obchodné rokovania, prekladový seminár, oblastné a interkultúrne štúdiá, praktická štylistika. Účastníci prieskumu odpovedali na 20 otázok: 19 zatvorených, vždy s výberom jednej z troch možností, a jednu otvorenú. Celkovo prišlo 28 odpovedí, čo predstavuje $72 \%$ účast' z počtu študentov danej kombinácie. Z toho $75 \%$ študentov bolo z bakalárskeho a $25 \%$ $\mathrm{z}$ magisterského stupňa štúdia. Kedže sme nezaznamenali výraznejšie rozdiely medzi odpovedami týchto dvoch skupín respondentov, výsledky dotazníkového prieskumu sme vyhodnotili ako celok.

\section{Výsledky a diskusia}

Prvá séria otázok mala za ciel' zistit', akej povahy bol autentický materiál a ako často bol využívaný na hodinách odborného francúzskeho jazyka. Na otázku, aký zdroj bol vo výučbe najviac zastúpený, $43 \%^{2}$ opýtaných uviedlo autentické dokumenty a $25 \%$ opýtaných uviedlo autentické dokumenty aj učebnicu v rovnakej miere. $32 \%$ respondentov uviedlo, že pracuje na hodinách iba s učebnicou.

\footnotetext{
2 Výsledné hodnoty v percentách sú zaokrúhlené na celé čísla.
} 
Najčastejšie používané sú materiály textové (75\%), potom obrazové (15\%) a napokon audiovizuálne (10\%), zvukové dokumenty študenti neuviedli vôbec. Na otázku, či súvisel autentický materiál s praxou, až $90 \%$ uviedlo značnú (50\%) alebo čiastočnú (40\%) súvislost', iba $10 \%$ odpovedajúcich nevidelo v tom žiadnu súvislost'.

Druhú skupinu tvorili otázky týkajúce sa didaktického využitia, čiže metód a spôsobov práce s autentickým materiálom na hodinách. Medzi odpoved’ami na otázku, či boli autentické dokumenty na hodine sprevádzané nejakými aktivitami, úlohami, cvičeniami, až 82 \% študentov označilo odpoved” „pravidelne“ a 18 \% možnost' „niekedy“. Možnost' „nikdy“ nevybral žiaden respondent. Išlo v prevažnej miere o skupinové aktivity (50\%), príp. kombináciu skupinových a individuálnych úloh v rovnakej miere (40\%), najmenej študentov uviedlo, že išlo iba o individuálne úlohy (8\%). Z odpovedí vyplynulo, že zadania úloh viedli najčastejšie k tvorivosti (61\%), príp. ako-kedy (36\%) a najmenej k pasivite (8\%). Na otázku, či vyvolal autentický dokument na hodine debatu, vyjadrenie postoja alebo argumentáciu, vybralo odpoved” „pravidelne“ $25 \%$, „niekedy“ 68 \% a „nikdy“ 7 \% študentov.

Tretia skupina otázok mala poukázat' na stupeň efektívnosti práce $s$ autentickými dokumentmi na hodine, ako aj na ich vplyv na rozvoj komunikačnej a interkultúrnej kompetencie. K otázke porozumenia autentického dokumentu sa vyjadrili študenti nasledovne: pre $75 \% \mathrm{z}$ nich to bolo bezproblémové, pre $25 \%$ náročné. Nikto neuviedol, že by to bolo vel'mi tažké. Za najnáročnejšie považujú porozumenie zvukového dokumentu (až $82 \%)^{3}$ a takmer rovnakú mieru obtažnosti pripisujú písomnému a audiovizuálnemu dokumentu (9\%). Čo sa týka oblasti jazykových kompetencií, až 90 \% študentov si vd’aka autentickému materiálu rozšírilo odbornú lexikálnu zásobu (z toho $40 \%$ značne a $50 \%$ čiastočne), gramatiku si zlepšilo $75 \%$ (z toho „značne“ $11 \%$, „čiastočne“ $61 \%$ a $28 \%$ uvádza možnost” „vôbec nie“). Najväčší prínos (až 100 \%) vidia respondenti v obohatení poznatkov z daného odboru (50\% značne, 50 \% čiastočne). Postoj k otázke získania nového interkultúrneho poznania pomocou autentického materiálu bol rovnako pozitívny: 42 \% uvádza jeho značný vplyv, 50 \% čiastočný. Na otázku, či autentické dokumenty ovplyvnili nejakým spôsobom zmenu postoja, názoru, predsudku, až $60 \%$ respondentov nevedelo odpovedat', $25 \%$ odpovedí bolo pozitívnych a $15 \%$ negatívnych. Odpovede na otázku, či autentický materiál pomohol študentom pri príprave projektu, prezentácie alebo úlohy, sa percentuálne zhodovali pri všetkých troch možnostiach: „značne“ (34 \%), „čiastočne“ (33\%) alebo „vôbec nie“ (33 \%).

Napokon štvrtou oblastou prieskumu názorov bol celkový postoj študentov k autentickým dokumentom používaným na hodinách, vrátane ich vplyvu na motiváciu k štúdiu jazyka. Väčšina študentov považuje implementovanie autentického

\footnotetext{
3 Túto odpoved' musíme brat' s určitou rezervou, vzhladom na to, že v predchádzajúcej otázke, aké dokumenty využívajú na hodinách, žiaden respondent neuviedol možnost' „zvukové“.
} 
materiálu do výučby za dôležité: možnost' „nevyhnutné“ uviedlo $43 \%$ opýtaných a možnost' „užitočné“ až $57 \%$. Nik z odpovedajúcich to nepovažuje za „stratu času“. Rovnako žiaden respondent neuviedol, že mu vyhovuje iba práca s učebnicou, naopak, $35 \%$ preferuje učenie iba pomocou autentických dokumentov a až $65 \%$ pokladá za najlepšie striedavé používanie učebnice a autentických materiálov. Naopak, iba malé percento opýtaných (15\%) priznáva záujem opakovane sa vracat' k autentickým dokumentom. Pri tejto otázke vybralo odpoved” „niekedy“ $50 \%$ a „málokedy“ až $35 \%$ študentov.

Posledná 20. otázka, s otvorenou možnost'ou odpovede, mala za ciel' monitorovat', čo považujú študenti za najdôležitejšie pri používaní autentických dokumentov vo výučbe (francúzskeho) jazyka. Respondenti sa vyjadrovali k vlastnostiam takýchto dokumentov, ich náročnosti, s ktorou súvisí ich porozumenie, ale taktiež $\mathrm{k}$ ich didaktickej aplikácii. Ako hlavné atribúty takýchto dokumentov uvádzajú zaujímavost', zrozumitel'nost', pestrost', aktuálnost', ale aj príbuznost' so študovaným odborom. Po obsahovej stránke by podla nich mali autentické materiály prinášat' nové poznatky. Z hladiska pedagogického využitia študenti požadujú, aby boli dokumenty zrozumitel'né aj pre nižšiu jazykovú úroveň a aby sa nová slovná zásoba, ktorú prinášajú, pre lepšie zapamätanie opakovala viackrát. Okrem toho preferujú skupinovú komunikáciu a nadväzujúce aktivity, ktoré ich nútia rozmýšlat' a viac zapájat' ich individuálne schopnosti. Za vel'mi dôležitý pokladajú aj výber vhodných tém s adekvátnou lexikálnou zásobou.

\section{Záver}

V príspevku sme hladali odpovede na otázku, aké miesto má v súčasnom jazykovom vzdelávaní autentický materiál a aké sú možnosti jeho implementovania do výučby odborného jazyka. Pomocou dotazníka sme chceli zistit', či je autentický materiál dostatočne efektívne využívaný vo výučbe odbornej francúzštiny a či motivuje študentov k štúdiu jazyka. Napriek určitým problémom, s ktorými sa študent alebo učitel' môže pri práci s autentickým materiálom stretnút', konštatujeme, že prevažujú jeho pozitívne stránky.

Na základe výskumu i vlastných pedagogických skúseností dochádzame k záveru, že implementácia autentického materiálu do procesu osvojovania si odborného cudzieho jazyka musí byt' primeraná, t. j. musí zohladňovat' vek a osobnostné predpoklady a preferencie členov učiacej sa skupiny, ako aj ich jazykovú úroveň a komunikačné ciele výučby. Aplikovanie autentických dokumentov vo výučbe nie je jednoduchou záležitost'ou, pretože si vyžaduje dôkladnú prípravu a dobrú organizáciu vyučovania a najmä systematickost'. Autentický dokument nemá byt' iba ojedinelým doplnkom či vyplnením časového priestoru na hodine, ale má sa stat' integrálnou súčastou celého výučbového procesu. Jeho začlenenie do danej fázy 
vyučovacej jednotky musí byt' v súlade so stanovenými ciel'mi a sprievodnými aktivitami.

Hoci sa na našom dotazníkovom prieskume nezúčastnili všetci študenti patriaci do cielovej skupiny, aj takmer trojštvrtinová vzorka nám priniesla dôležitú informáciu o tom, že sa na hodinách francúzskeho jazyka pracuje $s$ autentickými zdrojmi pravidelne. Až dve tretiny francúzštinárov majú dobré skúsenosti s autentickými dokumentmi na hodinách odborného jazyka, prácu s nimi vítajú a ich porozumenie im nespôsobuje vel'ké t’ažkosti. Potešujúce je aj zistenie, že autentické dokumenty neboli nikdy na hodinách samoúčelné, pretože boli väčšinou spájané so zadaniami a činnostami, ktoré podporili aktivitu a tvorivost' učiacich sa. Okrem nových poznatkov v danom odbore priniesli študentom významné rozšírenie odbornej slovnej zásoby a čiastočne i gramatiky. Až 90 percent opýtaných konštatovalo súvislost' dokumentov s praxou. Viac ako dvom tretinám opýtaných pomohol autentický materiál pri príprave projektov a prezentácií, ktoré sú dnes neoddelitel'nou súčastou hodín odborného jazyka. Toto sú podla nás dôvody, pre ktoré všetci študenti pokladajú začleňovanie autentického materiálu do výučby odborného jazyka za nevyhnutné alebo užitočné. V očiach študentov aplikovaných jazykov je autentický materiál vo výučbe nevyhnutný, a to tak pre rozvoj komunikačných kompetencií, ako aj pre prehlbovanie kultúrnej a interkultúrnej kompetencie. Určité rezervy vidia študenti v uplatňovaní aktivít smerujúcich k diskusii, k vyjadrovaniu kritického postoja a k logickej argumentácii, keďže iba štvrtina z nich uviedla, že sa s nimi stretávala na hodinách pravidelne.

Na záver konštatujeme, že sa potvrdilo, že na vysokoškolskom stupni vzdelávania sú autentické zdroje a materiály neodmyslitel'nou súčast'ou výučby odborného cudzieho jazyka, pretože pomáhajú pripravovat' absolventov pre prax. Sprostredkúvajú nové poznatky v odbore, ale aj o rôznych aspektoch života obyvatelov krajiny cielového jazyka. Sú zaujímavé, pestré a späté s aktuálnou realitou, čo tiež prispieva k pozitívnej motivácii učiacich sa. Vd’aka nim si študenti osvojujú cielový jazyk a rozvíjajú svoju jazykovú a interkultúrnu kompetenciu v konkrétnych komunikačných situáciách. Prieskum študentských názorov nám poskytol tiež niekol'ko zaujímavých postrehov a námetov, ktoré budú inšpiráciou pre našu d’alšiu pedagogickú činnost'.

\section{Literatúra}

Cortes, J. (1987). Une Introduction à la Recherche Scientifique en Didactique des langues. Paris: Crédif.

Couto Silva KenNiA, K. (2015). Le document authentique, un outil médiateur des interactions en classe de FLE. Revista Letras Raras, 4 (1). [online]. Dostupné z: http://revistas.ufcg.edu.br/ch/index.php/ RLR/article/download/397/300

CuQ J.-P. (2003). Dictionnaire de didactique du français langue étrangère et seconde. Paris: Clé International. 
ČURIOvÁ, H. (2017). Cudzojazyčné čítanie a slovná zásoba. Reading in foreign languages and vocabulary. Klúčové kompetencie pre celoživotné vzdelávanie VI. Prešov: Prešovská univerzita v Prešove. Dostupné z: https://www.pulib.sk/web/kniznica/elpub/dokument/Gogova2/subor/Curiova.pdf

DEFAYS, J.-M., \& DeLtouR, S. (2003). Le français langue étrangère et seconde. Enseignement et apprentissage. Sprimont: Editions Mardaga.

GajDÁčová Veselá, K. (2017). Text vo vyučovaní odborného anglického jazyka. Aplikované jazyky $v$ univerzitnom kontexte. Zvolen: Technická univerzita vo Zvolene, 7-15.

Homolová, E. (2003). Autentický materiál ako prostriedok rozvoja jazykových a komunikatívnych kompetencií žiakov. Banská Bystrica: UMB.

HRIvíKovÁ, T. (2012) Interkultúrna komunikácia z hladiska kontextu - alternatívny prístup ku štúdiu interkultúrnej komunikácie. Lingua et vita. I (1), 73-80.

KvaPIL, R. (2015). Kulturéma v kontexte podporného dokumentu. In Nové výzvy pre vzdelávanie v oblasti odborného jazyka a interkultúrnej komunikácie. Zborník vedeckých prác. Trnava: Slovenská spoločnost' pre regionálnu politiku pri SAV, 40-55.

LEMEUNIER-QUÉRÉ, M. (2006). Créer du matériel didactique: un enjeu et un contrat. Dostupné z: http:// www.francparler-oif.org/images/stories/dossiers/lemeunier_quere2006.htm

REPKA, R. (1997). Od funkcií jazyka ku komunikatívnemu vyučovaniu. Bratislava: SAP.

Spoločný európsky referenčný rámec pre jazyky. (2017). Bratislava: ŠPÚ.

\section{Autorka}

PhDr. Iveta Rizeková, PhD., Fakulta aplikovaných jazykov, Ekonomická univerzita v Bratislave, e-mail: iveta.rizekova@euba.sk

Iveta Rizeková pôsobí ako odborná asistentka francúzskeho jazyka na Fakulte aplikovaných jazykov Ekonomickej univerzity v Bratislave, kde aktuálne vyučuje odborný (ekonomický) a akademický jazyk. Na fakulte medzinárodných vztáahov vedie kurz všeobecnej francúzštiny. Od roku 2005 je kontaktnou osobou s Obchodnou a priemyselnou komorou v Paríži pri organizovaní skúšok na získanie medzinárodného diplomu z odbornej francúzštiny. Jej publikačná činnost' predstavuje vyše 60 príspevkov v odborných a vedeckých časopisoch a zborníkoch. Je autorkou a spoluautorkou viacerých vysokoškolských skrípt a učebníc vo francúzskom jazyku. Venuje sa oblasti všeobecnej a aplikovanej lingvistiky a francúzštine pre univerzitné ciele. Zaujíma sa o francúzske a slovenské reálie, ale aj o moderné pedagogické prístupy, ktoré prispievajú ku skvalitňovaniu jazykovej komunikácie. Bola riešitel'kou dvoch vedecko-pedagogických projektov KEGA a školitel'kou viacerých záverečných bakalárskych a diplomových prác a ŠVOČ vo francúzskom jazyku. 